\title{
The Defence Performance Measurement Framework: Measuring the Performance of Defence Organisations at the Strategic Level
}

\author{
Joaquim Soares*
}

Department of Economics, Management, and Leadership, Royal Military Academy

8 Rue Hobbema, 1000 Brussels, Belgium

TEL (0032)24413818, ORCID 0000-0003-1166-9984, Soares86@hotmail.com, https://www.linkedin.com/in/joaquim-soares-79643636

* Corresponding author

\section{Geert Letens, Ph.D. CPEM}

Department of Economics, Management, and Leadership, Royal Military Academy

8 Rue Hobbema, 1000 Brussels, Belgium

TEL (0032)24414021, ORCID 0000-0002-9006-8265, Geert.letens@gmail.com

Nathalie Vallet, Ph.D.

Department of Management, University of Antwerp

31Mutsaardstraat, 2000 Antwerp, Belgium

TEL (0032)658700, ORCID 0000-0002-4138-0228, nathalie.vallet@uantwerpen.be 
Wouter Van Bockhaven, Ph.D.

Department of Management, University of Antwerp

5 Boogkeers, 2000 Antwerp, Belgium

TEL (0032)473806590, ORCID 0000-0003-2911-3351, wouter.vanbockhaven@ams.ac.be

\author{
Heather Keathley-Herring, Ph.D.
}

Department of Industrial Engineering and Management Systems, University of Central Florida

12800 Pegasus Dr, P.O. Box 162993, Orlando, Florida, 32816-2993, USA

TEL (407)8234745, ORCID, 0000-0002-0236-3361, Heather.Keathley@ucf.edu

Eileen Van Aken, Ph.D.

Grado Department of Industrial and Systems Engineering, Virginia Tech

253 Durham Hall (MC 0118), 1145 Perry Street, Blacksburg, Virginia, 24061, USA

TEL (540)2316656, ORCID 0000-0002-8040-0973, evanaken@vt.edu 


\section{Abstract}

As the gap between strategic commitments and budgetary constraints continues to grow, defence organisations have introduced performance management initiatives to support decision-making and to improve governance. However, introducing managerial practices in public organisations, including defence, proves to be challenging. As performance management initiatives within defence suffer from an implementation gap, strategic benefits are not being harnessed. In our study, we first exploit the results of a Systematic Literature Review to better anchor the encountered challenges within literature. We then apply thematic analysis to a unique dataset from twelve NATO countries to propose a new defence-specific performance management framework for the strategic level. As the new framework preserves the benefits of existing initiatives while mitigating most recorded challenges, it is proposed as a new guide for designing and assessing defence performance management efforts. Thereby, professionals and scholars are provided with a powerful instrument to address the implementation gap. Moreover, the theoretical and empirical lens adopted ensures alignment between performance management initiatives, defence policy, defence strategy, and strategic objectives. Notably, policy goals and strategic "ends" are clearly connected to critical processes and resources. Thereby, the new framework better supports discussions with key defence stakeholders pertaining to the gap between commitments and constraints.

\section{Keywords}

Defence Policy, Defence Strategy, Performance Management, Performance Measurement, Conceptual Framework

\section{Introduction}

Scholars widely agree that defence organizations are facing important strategic challenges. This includes the need to manage large and complex systems, if not the organisation itself, within an increasingly uncertain environment (Saxi 2017; Tama 2018). The proliferation of stakeholders wanting to influence defence policy and strategy makes this even more challenging. Further, 
powerful stakeholders still mandate constant readiness despite resource allocation constraints (Edmunds et al. 2016; Tama 2018). As these challenges continue to grow, defence organisations have introduced indispensable managerial tools and practices to support the management of the overall organisation (Erbel 2017). This includes the use of performance management and measurement systems that aim to support strategic decision-making and evaluation processes, and to ensure any degree of coherence, predictability, efficiency, and effectiveness (Davis 2018; Lawrence and Jermalavičius 2012).

Whereas there is no consensus on the precise approach or definition of performance measurement and management initiatives (Bourne and Bourne 2005; Chearskul 2010), it is generally accepted that a performance measurement system (PM System) is designed around a set of Key Performance Areas (KPAs), objectives, and metrics (Lu and Chen 2011; Neely, Gregory, and Platts 1995) to support the broader management efforts within an organisation (Bourne et al. 2000; de Waal 2002). All together, the PM System and its different types of objectives and metrics are often referred to as the Performance Measurement Framework or PMF of an organisation (Bayne and Raymond 2003). At this time, most PM initiatives within defence are centred on PMFs initially developed outside the realm of defence, such as the Balanced Scorecard (Kaplan and Norton 1992) or the Logic Model (Ivancik and Necas 2012; Marquis et al. 2006). However, defence organisations have not been very successful in implementing PM Systems based on such frameworks, and have thereby failed to harness the strategic and organisation-wide benefits (Cavoli 2004; Mol and Beeres 2005; Streit 2004). The resulting gap between strategic PM System design and its successful organisation-wide implementation is similar to the one reported for other decision - and policy - making initiatives including defence 
reform (Tama 2018). Even if such an implementation gap creates a lot of frustration amongst the organisation and its stakeholders (Kingdon 2011), scholars have largely ignored such defence management problems to date (Norheim-Martinsen 2016; Tama 2018). Therefore, this paper aims to address this research gap, contributing to the understanding of how to design PM Systems for large and complex organisations with a multitude of stakeholders.

There are two main contributions this work wants to make. First, it builds on the recommendations of Bourne et al. (2002) and Keathley and Van Aken (2013) using a contextspecific and structured approach to develop a new, comprehensive, defence-specific, and strategic-level PMF better suited to support defence decision-making. Notably, the theoretical and empirical lens adopted ensures alignment between the PMF, defence policy, defence strategy, and strategic objectives. Moreover, policy goals are clearly connected to critical processes and resources constraints, which should be helpful during high-level discussions with key stakeholders. For this purpose, research was conducted within the auspices of a NATO Research Task Group (RTG). Within the RTG, data was collected from twelve countries using semi-structured interviews as well as strategy- and PM-related documents that the participating nations shared. The qualitative data was then analysed using a thematic analysis approach adapted from Braun and Clarke (2006), leading to the creation of the new Defence Performance Measurement Framework or DPMF. The DPMF is therefore not the result of anecdotal evidence of management practices in a single nation, but is rather the result of a multinational and systematic comparison of defence management practice within twelve NATO countries. This is recognised as both unique and crucial, addressing a clear gap identified in the literature (Lawrence and Jermalavičius 2012; Norheim-Martinsen 2016). The second major contribution 
of this work is that it provides a powerful instrument to help defence professionals and scholars better address the persistent implementation gap impacting the field. Since the DPMF builds upon the stated benefits of existing frameworks while mitigating most of the recorded challenges, it is proposed as a new guide for the design and evaluation of strategic-level defence PM initiatives. Ultimately, exploitation of our results should positively influence the rate of successful adoption of PM Systems within the military.

The remainder of the paper is structured as follows. First, a literature section summarises the main benefits and challenges associated with PM frameworks currently used within defence organisations. The research objective and the underlying research questions are then articulated, followed by the methodology section and the new framework development process. Thereafter, the main results are presented including the description of the DPMF and a national case study illustrating the application of the study results within a NATO member. This is followed by a comparison of the DPMF with existing PM frameworks. Finally, we summarise the main contributions of this study and point to limitations and future research opportunities.

\section{Literature Study}

The design of PMFs has varied over time (Bourne et al. 2000) and is impacted by factors such as stakeholder relationships, top-level support, and perceived benefits (Waggoner, Neely, and Kennerley 1999). At the strategic-level, these benefits can be broadly categorised as 
organisation-wide ${ }^{1}$, of strategic nature ${ }^{2}$, or process-related ${ }^{3}$. Given these numerous benefits, several PMFs have been adopted in the private and public sector with the Balanced Scorecard (BSC) of Kaplan and Norton (1992) being the most prevalent. It contains goals and measures in four domains of performance, being "financial", "client", "internal process", and "innovation and growth". Another prevalent framework, the Logic Model, structures organisational performance according to the value production process in terms of clearly defined objectives and measures related to "inputs", "processes", and "outputs" of the organisation (Beeres, De Waard, and Bollen 2010). Even if the BSC and the Logic Model are the most widely disseminated frameworks (de Waal 2002; Keathley 2016), many other frameworks exist, including more refined ones for the public sector such as the Performance Prism (Neely, Adams, and Crowe 2001). Within this framework, the various stakeholders of the organisation enjoy a prominent role, by putting a lot of emphasis on the balance that needs to exist between stakeholder expectations and stakeholder contributions. Overall, even if one may perceive these different frameworks as competing, they essentially offer unique contributions. As a result, it would be valuable to combine the individual benefits into a coherent whole (Woodley, 2002).

\section{Main defence benefits}

In the defence-specific literature on PM Systems, the stated benefits are similar to those found in

\footnotetext{
${ }^{1}$ Such as better organisational learning, knowledge sharing, understanding of the strategy and strategic awareness, management, employee commitment, and quality.

${ }^{2}$ Such as better strategic communication, organisational reputation, and legitimization.

${ }^{3}$ Such as better focus, decision-making, monitoring, improvement initiatives and results, feedback, tracking, testing, and validation of the strategy.
} 
the wider literature. First, PM Systems are said to provide a range of organisation-wide benefits including better strategy implementation, increased strategic awareness amongst stakeholders, better alignment, better synergy between different units and levels of decision-making, and increased empowerment (Lassen 2010; MacBryde et al. 2012; NATO 2011). Second, as far as strategic benefits are concerned, PM Systems are known to support strategic reporting, oversight, communication, storytelling, and discussions towards key stakeholders, and are therefore needed to obtain buy-in from external audiences (Cavoli 2004; Tama 2018; Tomlyn 2005). Third, PM Systems support a variety of processes such as strategic planning, resource allocation, capability development, organisational change, operational planning, operational control, and program evaluation.

\section{Dominant defence frameworks}

Keathley, Du, and Olliges (2015) observe that most initiatives within defence organisations have either been attempts to introduce the BSC, the Logic Model or consist of customisations of one of these two frameworks. One of the most notable customisations within defence organisations, similar to other public organisations, is the replacement of the "financial" perspective of the BSC by the organisation's core functions (Ivancik and Necas 2012) or stakeholders (Kem et al. 2000; Sedosheva 2011). However, most initiatives identified in the literature focus on functional and structural levels other than the strategic-level. This includes a focus on a particular service (Bush 2005; Stevens 2004), department (Beeres, De Waard, and Bollen 2010; Hepler 2008), aspect (Beeres and Bogers 2011; Hackleman, Johnson, and Ahner 2014), and entity (Schriver 2000; 
Webb and Candreva 2010). Further it can be noted that different services ${ }^{4}$ have different priorities (Posen 2016) and therefore tend to use different frameworks to optimise their performance (Keathley, Du, and Olliges 2015), leading to various performance-oriented mental models within the overall organisation. Finally, none of the frameworks identified seemed to be designed based on multinational initiatives.

\section{The challenges faced when designing PM Systems within defence organisations}

Despite the general trends previously mentioned, there are numerous specific challenges recorded in the literature relating to the successful adoption of PM Systems within a defence context. First, strategic management is double-faced, i.e. there is possible misalignment between the military-strategic and politico-strategic functions (Huntington 1981; Lawrence and Jermalavičius 2012). Policy goals may therefore not be appropriately translated into strategic “ends" (Kingdon 2011). Second, the need to demonstrate accountability and value to an increasingly diverse and complex set of stakeholders complicates the PM effort (Band 2004; Boynton and Vaughan 1998; Tomlyn 2005). Third, within defence organisations themselves, it remains particularly challenging to define and measure some of the KPAs and critical "outputs" (Beeres and Bogers 2011; NATO 2011). According to Tomlyn (2005), this is because a significant part of the value generated by defence activities are cognitive and non-tangible (e.g. prevention). The desired military effects may be second, third or fourth order and linking cause and effect may be difficult whenever the underlying military activities are exercised in

\footnotetext{
${ }^{4}$ The Air Force, Army, Coast Guard, Navy and Marine Corps in the U.SA. for example.
} 
conjunction with other instruments of Government. Finally, given the difficulties in identifying stakeholders and measuring "outputs", many defence systems seem to rely on the measurement of "inputs" , and thereby fail to help defence managers focus on the delivery of services (Beeres, De Waard, and Bollen 2010; Marin 2012; Mol and Beeres 2005) .

Besides these stakeholder-related challenges, several design-issues further complicate the implementation of PM Systems within defence organisations. First, defence organisations tend to be amongst the largest, most complex, and most diverse public sector organisations with a huge number of activities: this complicates any PM effort (Marquis et al. 2006). As a result, existing PM efforts that are based on highly consolidated frameworks do not adequately reflect this complexity (Beeres and Bogers 2011; Cavoli 2004). Second, the previously mentioned use of different performance-oriented mental models within the organisation hinders the successful organisation-wide adoption of PM Systems as this likely creates duplication, incompatibilities and misalignment between strategic-level leaders using different "languages" to discuss performance (Folan and Browne 2005). Third, many existing PM efforts over-emphasise

\footnotetext{
${ }^{5}$ Such as the level of spending or the availability of resources.
}

${ }^{6}$ In turn, failure to align the "outputs", "processes" and "inputs" has led to huge defence shortfalls over the years. This includes deployments without adequate resources, as is illustrated by the massive volume of outsourcing contracts given to private military and security companies to sustain current operations (Erbel 2017). Moreover, effective strategy development is hampered and policy decisions are restrained to "inputs" and "processes" without adequate consideration of the "outputs" (Kingdon 2011). 
efficiency and profitability-related metrics which are not the ultimate criterion of performance for defence organisations (Beeres and Bogers 2011; Marquis et al. 2006; Tomlyn 2005). Linking this to the failure of defence organisations to use specific military terminology in their PM efforts clarifies why many military PM management initiatives suffer from a lack of face-validity and legitimacy (Keathley, Du, and Olliges 2015).

Finally, it appears that defence organisations are facing challenges in conceptualising dependencies between critical performance information: they fail to connect their PM Systems to their defence and national strategy by means of meaningful, overarching, and visual tools that adequately reflect the decision patterns of the strategic decision-makers (NATO 2020). Such tools that by means of arrows between graphical objects visually hypothesise dependencies between an organisation's strategy, goals, and performance are referred to as strategy maps (Neely and Jarrar 2004) ${ }^{7}$. Even though strategy mapping was not originally part of the traditional PMFs (Hepler 2008), it is an integral part of a modern PMF (Ivancik and Necas 2012). As several benefits are associated with the use of strategy maps (Ittner and Larcker 2003; Kaplan and Norton 2004, Morgan 2015), failure to visualise causal linkages hinders organisations to gain the full potential of their PM System. This is often linked to problems during the cascading of the PM System, difficulties in developing non-financial measures, and the inability to resolve contradictory performance information (Chearskull 2010). As strategy maps have been successfully designed and used at the lower levels of defence organisations, defence organisations may benefit from additional reflection on the design of such maps at the strategic-

\footnotetext{
${ }^{7}$ Also referred to as cause-and-effect maps and success maps.
} 
level.

\section{Research Objective and Research Questions}

Following a literature review to better comprehend the challenges hindering existing PM initiatives within defence, our study further aims to address these challenges by focussing on PM System design. While PM System design quality is a critical factor for successful PM System implementation (Arnold 2005; Keathley and Van Aken 2013), and any PM System design needs to adequately reflect the significance of the business context (Chearskul 2010; Franco and Bourne 2003; Martinez and Kennerley 2005), we failed to identify any suitable strategic-level and defence-specific PMF. As a framework designed using a context-specific and structured approach could mitigate many of the previously summarised challenges (Bourne et al. 2002; Keathley and Van Aken 2013), the main objective of this study became to design a new, comprehensive, defence-specific, and strategic-level PMF better aligned with defence policy and defence strategy, and therefore better suited to support decision making and high-level defence discussions with key stakeholders.

Our research objective can be decomposed into the following set of research questions:

1) What are the main perspectives, KPAs, and strategies that compose a new generic, comprehensive, and strategic-level framework for defence organisations?

2) How does the proposed framework better connect defence performance with defence policy and defence strategy? 
3) How can the proposed framework serve as a guide for the design and evaluation of strategic-level defence PM Systems?

\section{Methodology}

The diversity and complexity of the challenges mentioned led NATO's Science and Technology Organisation (STO) to establish a RTG named SAS-096 to investigate the state of play of PM Systems within NATO nations ${ }^{8}$. Within the RTG, data from twelve countries was primarily collected through semi-structured interviews and the evaluation of national PM-, policy-, and strategy-related documents. This main source of data was complemented by the exploitation of the results of a Systematic Literature Review (SLR) focused on the implementation of PM Systems within defence organisations (Keathley, Du, and Olliges 2015).

While the RTG sent the survey to all NATO nations and partners, ultimately twelve countries agreed to participate. While the exact positions of the individuals taking the survey differed between countries, all participants were staff at the strategic-level, either in the defence ministry or the defence forces, involved with the overall management of the defence organisation or the nation's PM System. All interviews took approximately one hour and thirty minutes. As participants were guaranteed personal and national anonymity, no analysis, results, or insights will be shared that could lead to the identification of any particular nation.

\footnotetext{
${ }^{8}$ Despite the fact that the STO is one of the most innovative and analytically rigorous institutions with a far reaching impact within NATO, there is a surprising paucity of academic analysis pertaining to its activities (Morgan 2015), and our study therefore offers incremental remedial.
} 
The survey in itself consisted of an introduction section, a background participant information section, and a section on definitions, followed by the qualitative and quantitative questions on the design of the nation's current PM System. These questions focused on the kind of information considered critical for the organisation or its KPAs, the presence of overarching tools such as a BSC or strategy maps, domains in which measurements and assessments were conducted, the different measures used by the organisation, and KPAs that were considered difficult to measure. For the quantitative questions, a previously validated questionnaire on PM (Chearskul 2010) was adapted to reflect practices within the defence context. For the responses, a six-point Likert scale for agreement was used. The resulting quantitative data was used to visualise overall patterns in the data and to identify best practice nations versus low PM maturity nations. The qualitative questions enabled the participants to share personal perspectives on national problems and to clarify the current state of PM System practices within their organisation.

Participants were also requested to share illustrations, national strategy-, policy-, and PM-related documents for subsequent evaluation. These documents referred to an individual nation's stakeholders, defence policy, defence strategy, strategic objectives, and other pertinent PM System information. The documents received were diverse in nature and included leadership vision statements, defence policy documents and whitepapers, defence strategy documents, defence reports, and pertinent laws. Given the profile of the respondents and the types of documents analysed, the level of analysis of this study is limited to an individual nation's strategy and its strategic-level PM effort. 
Conducting research within the context of NATO is probably the most effective (if not the only) forum within which defence organisations will agree to share information on their PM Systems. Several characteristics testify of the diversity of the sample ${ }^{9}$. However, as in other PM studies (de Waal, Kourtit, and Nijkamp 2009), it is reasonable to assume that organisations which had enjoyed more success in adopting PM Systems were more likely to participate. Therefore, even if there was diversity in the quality and quantity of data provided, our study may have undersampled nations with less mature PM Systems. This is further supported by the responses of two nations, who declined to participate due to the lack of PM systems at the strategic-level. Despite this, the level of diversity in our sample corresponds to the generic requirements described above. As a result, the overall structure of the results derived from the most common strategic goals and objectives identified should remain valid for all countries.

\section{The Framework Development Process}

The data collection process generated twelve data points with a significant amount of qualitative data that was further analysed using a thematic analysis approach adapted from Braun and Clarke (2006). Using a qualitative inductive approach preserved the rich context-bound information that

\footnotetext{
${ }^{9}$ Including geography, defence expenditure, percentage of defence expenditure with respect to Gross Domestic Product (GDP), the size of the active armed forces, the size of the active armed forces with respect to the population, the type of armed forces or the ambition level, the deployment commitments, the Government's effectiveness, and the number of years in NATO.
} 
was essential to answering our research questions and ultimately to better comprehend the nature, depth, and breadth of the relationships and patterns being studied (Creswell 2003). The five phased process (depicted in table I) started with the "familiarisation with the data" (Phase One) based on the responses to the open questions of the questionnaire. Generating an overview of the responses of all nations for the open questions facilitated a general understanding of the state of play of PM within defence organisations. In doing so, KPAs, strategic objectives, metrics, and challenges were identified leading to an initial list of objectives, metrics, and tools. For example, the KPA "national credibility" was identified incorporating the following strategic objective: "Armed forces play an active role in the field of security, defence, and armaments policy on a national and international level". Two quantitative underlying metrics were identified being "the percentage of the commander's intent that have been met" and "the percentage of domestic and continental defence operations that have successfully achieved their operational objectives". One qualitative tool was also identified being a "yearly public opinion survey".

[Table I. near here]

Since the design of a PM System is principally a cognitive exercise that needs to take the expectations of stakeholders into account by expressing them in terms of strategic objectives and underlying performance metrics (Bourne et al. 2000), the main aim of Phase Two was the systematic identification and subsequent coding of the KPAs, strategic objectives and measures. For this purpose, the results of Phase One were used as a lens to evaluate the documents provided by nations. In doing so, the resulting PMF consists of themes that are tightly aligned with defence policy, defence strategy, and strategic objectives. Such an approach based on a 
clear understanding of high-level objectives and principles in designing defence strategy tools is widely supported by scholars (Davis 2018: Kingdon 2011; Lawrence and Jermalavičius 2012). In addition, Phase Two also consisted in the generation of concept maps for the participating nations. An example of such a concept map is provided in figure 1. During the mapping effort, an open coding process was deliberately pursued thereby omitting the unending number of variables that can influence defence performance and which may be completely exogenous to the organisation. It is also not possible to depict all the dependencies between the numerous themes while conserving some degree of readability. By only retaining the relationships that are most replicated in the data and discussions however, the mapping effort complies with Kaplan and Norton's (2004) definition of strategy mapping but also makes the results robust and generalizable, which are desirable characteristics when developing concepts according to Eisenhardt and Graebner (2007).

[Figure 1. near here]

Next, Phase Three consisted of the identification of dominant themes and the development of a preliminary framework based on these dominant themes. As recommended by Tama (2018), themes were only selected as "dominant" through confirming evidence from a variety of data. Validity, reliability, and generalisability are further strengthened by the fact that two researchers proceeded independently from Phase One to Three with a third researcher being involved in case of divergence to obtain a consensus after detailed discussion (Golafshani 2003; Hepler 2008). The preliminary framework and results were then shared with a panel of PM experts identified 
through professional networks and with defence Subject Matter Experts (SME) through a presentation at a NATO panel meeting consisting of defence academics and practitioners. Based on the feedback received, the code structure of dominant themes and sub-themes was revised to categories and sub-categories.

One of the key insights gained during this phase was how closely military strategic cognition, the relationships, and the coding results were found to fit with the overall approach of the Logic Model (“input" - "process" - “output", or better known within NATO as "means" - "ways" “ends”) (Erbel 2017; Kingdon 2011; Perry 2013). Another insight, perhaps less surprising, is the resemblance of some themes to elements of the DOTMLPFI (Doctrine, Organisation, Training, Materiel, Leadership and Education, Personnel, Facilities, and Interoperability) concept for NATO capability planning. Incorporating this terminology in the subsequent phases enhances the face-validity of the proposed framework for defence stakeholders.

Next, Phase Four consisted of a detailed iterative analysis of the documents provided by the two nations with the most mature PM Systems. Maturity was determined within the RTG by means of a hierarchical cluster analysis of the quantitative results of the survey ${ }^{10}$. The resulting code definitions and structure were shared with the national RTG representatives who reviewed the

\footnotetext{
${ }^{10}$ Interestingly, these two nations have a leadership role within NATO given their relative size, sophistication, and interest in international security, due to which many European states follow their example when contemplating organisational change and defence reform (Erbel 2017).
} 
coding repeatedly to ensure the accuracy and relevancy of the results. This process ensured the findings enjoy a NATO-wide consensus within the RTG.

Last but not least, Phase Five consisted of the final definition of mutually exclusive and collectively exhaustive categories and sub-categories as well as the determination of the main relationships between them. This resulted in the final code structure depicted in appendix one. Together, the perspectives, the performance categories, their subordinate sub-categories, the underlying relationships, and the supporting long list of strategic objectives and metrics constitute the proposed generic, comprehensive, and strategic-level Defence Performance Measurement Framework or DPMF.

\section{Results}

\section{The DPMF: A New Generic, Comprehensive, and Strategic-Level Framework for Defence Organisations}

The DPMF follows the overall structure of the Logic Model and thereby consists of three main perspectives: "ends", "ways", and "means". These perspectives contain seventeen underlying categories (read KPAs) and 77 underlying sub-categories in total with an average of five subcategories per category. Each sub-category then contains a set of strategic objectives which may be backed by metrics. While the categories and sub-categories have been structured to be mutually exclusive, nations may use the same strategic objective or metric within the context of 
multiple sub-categories, categories, or perspectives. For example, "number of personnel in defence in absolute numbers" was found to serve as a metric to reflect performance within “international credibility" (“ends"), "national transformation initiatives" ("ways") and the "evaluation of manning and personnel readiness" ("means"). Similar to classical strategy maps (Kaplan and Norton 2004), the underlying relationships of the DPMF can be explained from "means" to "ends" (bottom-up: as in the deeper explanation of the DPMF in the following paragraphs) or from "ends" to "means" (top-down: as depicted in the visualisation of figure 2).

[Figure 2. Near here]

First, the "means" perspective pertains to the tangible and intangible assets required to conduct all organisational activities and ensure either strategic parity or competitive advantage. As such, the budget allocated by a nation's Government enables the acquisition and management of all the other resources (Perry 2013). These other resources correspond to their own category in the framework, namely: "infrastructure assets", "information systems”, "science technology and knowledge", "information and intelligence", "portfolios of personnel", and "inventories of equipment”. Since some of these input-based KPAs and their combination constitute the backbone of traditional defence PM efforts (Beeres, De Waard, and Bollen 2010; Mol and Beeres 2005), their inclusion in the DPMF was relatively straightforward. However, science-, technology- and knowledge-related goals and measures only found inclusion in the DPMF due to the priority put on these categories by the most mature nations. Less mature nations may not be focusing on this category, either due to resource limitations, or due to a blind spot in their 
national policy and strategy. The importance for this category in the literature as a source of competitive advantage is abundantly clear however (Davis 2018; Jensen 2018). Ultimately, each category pertaining to the "means" perspective (or a combination of categories thereof) enables activities and processes taking place within the "ways" perspective.

Next, the "ways" perspective refers to the main activities and processes that underwrite the achievement of organisational objectives and stakeholder goals. The categories included within this perspective are: "transformation and continuous improvement initiatives", "capability development and integration initiatives", "military collaboration and ensuring interoperability with allies", "overarching command \& control processes and supporting services", and "force structure production and renewal processes". Within this perspective, the DPMF encompasses a more holistic view compared to existing PM initiatives where measurement efforts are usually geared towards resources management, operational planning, and procurement (Ivancik and Necas 2012). Also, since several of these categories (and sub-categories) bear close resemblance to the DOTMLPFI paradigm, this should enhance face-validity for military leaders as previously discussed. Further, whereas "capability development and integration", "transformation and continuous improvement", "force structure production and renewal processes", and "military cooperation with allies" are commonly accepted as KPAs for modern defence organisations (Hill 1974; Marin 2012; NATO 2011), "military cooperation with allies" is reputed as complex (Kingdon 2011; Ong 2003) and therefore also absent from most traditional framework-based efforts (Keathley, Du, and Olliges 2015). Our findings confirmed that the performance area itself seemed to be well present as a strategic thrust in national strategy documents whilst also observing a lack of clearly defined underlying measures. Therefore, it seems more appropriate to 
characterise this category as a measurement gap rather than a blind spot. Last, "overarching command \& control processes and supporting services" houses the central cross-service integration, coordination, and synchronisation mechanisms and institutions that are described as so important in the literature (Lindsay and Gartzke 2020; Morgan 2015). These mechanisms and institutions aim to balance priorities, enhance joint capabilities, and avoid tension, rivalry, redundancy, and over-consumption of scarce resources. Eventually, the interaction of actions and processes taking place between the categories of the "ways" perspective and the previously mentioned categories of "means" perspective enable changes in a nation's defence capabilities, in the structure of its defence force, and in the functioning of the organisation itself. This ultimately enables achievement of objectives contained in the categories and sub-categories of the "ends" perspective.

Finally, the "ends" perspective refers to the vast majority of stakeholder goals and policy objectives that have to be achieved. The categories contained within this perspective are "ready force elements", "mission outputs and effects", "national interests and defence \& security needs", "international credibility", and "national credibility". "Ready force elements" is a rather straightforward KPA for defence organisations (Davis 2018; Mol and Beeres 2005; Perry 2013). "Mission outputs and effects" however is a category that was typically absent from most BSCtype frameworks (Keathley, Du, and Olliges 2015) and was also reported as difficult to manage and measure (Beeres and Bogers 2011; NATO 2011). Similarly, to the "military cooperation with allies" category, our study indicates that this performance area is omnipresent in national policy and strategy documents. However, the big diversity and variety in measures that we found indicate that the precise meaning and definition of this KPA is often lacking. Next, "national 
credibility" and "international credibility" integrate the need to demonstrate performance towards the main strategic stakeholders previously reported in the literature (Cavoli 2004; Kingdon 2011; Perry 2013). For example, the credibility towards both international and national stakeholders is enhanced when there is a constant development and maintenance of capabilities which contributes to a constant production and renewal of ready force elements. Enhanced credibility provides a nation with a better bargaining position to fulfil its vital interests and security preferences (Chong 2015; Ong 2003) as characterised by the "national interests and defence \& security needs" category ${ }^{11}$.

\section{The DPMF as a strategy map: Connecting defence performance and defence strategy}

As is required for a modern framework, the DPMF serves as a strong basis for strategy mapping, thereby offering several benefits. First, since the DPMF and strategy map were developed concurrently, problems as described by Bourne et al. (2000), Hepler (2008), and Ittner and Larcker (2003) such as misalignment between strategy, objectives, and measures are mitigated. Second, as claimed by Kaplan and Norton (2004), the depiction of the main relationships between the selected categories should encourage defence stakeholders to visualise, contextualise, make sense of, and track organisational performance while assessing the impact of that performance over time (Morgan 2015). Third, as is highlighted by Ivancik and Necas (2012) and Sedosheva (2011), strategy maps help in communicating the organisation's overall strategy

\footnotetext{
${ }^{11}$ For a deeper discussion on bargaining around national (or vital) interest, power, and values and how this is linked to the generation of different credibility options, we refer to Lindsay and Gartzke (2016) and Morgan (2003).
} 
graphically to stakeholders. When used in a top-down manner, the DPMF supports the communication of defence strategy and goals across the organisation. However, when read bottom-up, it can be useful to generate stakeholder buy-in for additional "means" and for clarifying the "why" of specific bottom-up initiatives.

Looking at the DPMF as a strategy mapping tool also reveals two main strategies driving the agenda of defence organisations: an innovation strategy and a productivity strategy. The innovation strategy focuses on the development of new or upgraded capabilities enabling the organisation to adapt to future threats. Such a strategy requires capital investments, science and technology contributions from the industry, and competent and trained personnel to operate modern weapon systems (Erbel 2017; Kingdon 2011; Posen 2016). Nations pursuing an innovation strategy emphasise dependencies between objectives contained within "portfolios of personnel" ("means"), "science technology and knowledge" ("means"), "portfolios of equipment" ("means"), and "capability development and integration" ("ways") thereby leading to ready force elements ("ends") and enhanced credibility ("ends"). While less mature nations seem to pursue this strategy in collaboration with allies, more mature nations implement this strategy on their own (Sauer 2015; Saxi 2017). The productivity strategy or the "do more with less" strategy on the other hand focuses on enhancing organisational productivity. This strategy is often instilled by the national Government (Morgan 2015; Tama 2018). Nations following this strategy tend to focus on change and continuous improvement by reducing, rationalising, or redistributing personnel, materiel, and infrastructure. Information systems such as enterprise resource planning tools and cost accounting systems support the implementation of such efficiency initiatives (Goldman 2004; Levene 2013; Perry 2013). In turn, a more efficient and 
more agile organisation has a better perceived chance of "mission success" as it is able to channel more of its resources to the front lines when needed (Porter and Mykleby 2012). Improved mission "outputs" are in turn directly linked to the fulfilment of national defence and security objectives and credibility towards national and international stakeholders (Egnell 2006). Accordingly, within the DPMF, pursuance of such as strategy implies emphasis on dependencies between objectives contained within "portfolios of information systems" ("means"), "infrastructure assets" ("means"), "portfolios of personnel” ("means"), "transformation and continuous improvement" ("ways"), "mission outputs and effects" (“ends") and "credibility" categories ("ends").

\section{Using the framework as a guide for the design and evaluation of strategic-level defence} PM Systems

To explore what insights the DPMF can provide with regard to the design and evaluation of defence PM Systems, we assessed the existing strategic-level defence PM System of one of the participating nations. Several semi-structured interviews of 60 to 180 minutes were conducted with the nation's SMEs responsible for the design and implementation of strategic-level defence PM initiatives and their adoption within the overall organisation. The interview guide was structured around the DPMF and consisted of open and quantitative questions (Likert scale from 1 to 6). The SMEs were asked to indicate which categories and sub-categories seemed relevant to their organisation and to clarify whether or not these were the subject of actual existing measurements. Further, additional strategic-level defence and Government documents provided by the SMEs were also evaluated, leading to several interesting results. 
First, the SMEs considered the DPMF as comprehensive: no KPA was deemed to be missing and all categories received an average relevancy score between four and six on the Likert scale. This also testifies of the DPMF's face-validity at the strategic-level. Further, since comprehensiveness is one of the key characteristics of the DPMF, a comparison of the DPMF's categories and subcategories with the nation's defence strategy and PM efforts was conducted to assess the degree to which all the strategic areas of interest were covered by the nation (i.e. to detect any blind spots). While some missing categories such as "infrastructure Assets" were still monitored at the sub-strategic level, several categories such as "science, technology, and knowledge" seemed to completely escape from senior management attention. In addition, by systematically questioning which subcategories were the subject of actual measurements, several KPAs were found to constitute measurement gaps, i.e. whereas they were mentioned several times in the policy and strategy documents, they were not covered by any metrics. For example, no metrics were identified for some sub-categories under "international credibility" whereas these had received a relevancy score between five and six. While certain blind spots may exist by choice (e.g. due to budgetary constraints), the existence of measurement gaps leads to the question whether the actual metrics are aligned with the overall defence strategy (Bourne et al. 2000; Ittner and Larcker 2003) and whether the KPAs that are not measured receive adequate leadership attention (Arnold 2005) ${ }^{12}$. Overall, the SMEs confirmed that the nation's PM efforts could benefit from the DPMF and its associated long list of objectives and metrics. In using the DPMF as an

\footnotetext{
12 The degree of coverage (i.e. the number and size of the blind spots) and the number of measurement gaps provide a strong indication of the overall maturity of a PM System (Wettstein and Kung 2002). In the case of the assessed nation, the maturity level was found to be coherent with the one indicated in the NATO proceedings.
} 
evaluation instrument, valuable insights with regards to PM System deployment, alignment with policy and strategy, blind spots, measurement gaps, ownership, focus, and maturity were generated that supported further development of the existing PM System.

\section{Discussion}

\section{Comparison of the DPMF with traditional frameworks}

The DPMF does not aim to compete with any of the other existing frameworks. Instead, it preserves their many stated benefits into a defence-specific and more coherent whole. As the overlap between the DPMF, the Logic Model, and the DOTMPLFI paradigm has been emphasised throughout the paper, the following paragraph compares the DPMF with two other traditional frameworks previously referenced: the BSC (Kaplan and Norton 1992) and the Performance Prism (Neely, Adams and Crowe 2001).

As far as the BSC is concerned, the structure and the nature of the perspectives is significantly different. Within the perspectives of the DPMF, the high number of KPAs retained as categories and sub-categories better reflect the diversity and complexity of a nation's defence policy and strategy. Further, the use of defence-driven terminology within the KPAs improves the legitimacy, buy-in, and face-validity of the framework towards its different stakeholders (Chesley and Wenger 1999). However, important quality-determining design aspects often linked to the BSC such as balance (Bourne et al. 2000; Kaplan and Norton 1992; Keathley 2016) and the visualisation of cause and effect relationships through strategy mapping (Kaplan and 
Norton, 2004) form an integral part of the DPMF. For example, whereas the literature indicates a heavy resource-based reporting-focus in existing defence initiatives (Beeres, De Waard, and Bollen 2010; Beeres and Bogers 2011), the perspectives, categories, and sub-categories of the DPMF strive for a more balanced view of defence activities from "inputs" over "processes" towards "outputs", as well as between short-term and long-term strategic thrusts as is highlighted by the two strategies described in the previous sections (Marquis et al. 2006; Posen 2016).

The DPMF also strives for balance between different stakeholders (internal, external, national, international...) by giving them prominence in various categories and subcategories. Most stakeholder and policy goals are characterised by categories and sub-categories of the "ends" perspective while most stakeholder contributions are characterised by categories and subcategories of the "means" perspective. Focusing on the overall value and service delivered to stakeholders in a transparent way increases organisational legitimacy and thereby the primary resources of the organisation are secured (Christiaens, Heene and Vanhee 2009; Tama 2018). In following this core design philosophy of the Performance Prism (Neely, Adams, and Crowe 2001), the DPMF serves as an important tool to align and to debate the achievement of political "ends" with military means as is described by Lindsay and Gartzke (2020) and Perry (2013). It makes clear to key stakeholders how enhanced expectations need to be backed-up by an adapted force structure and posture, and therefore balanced by an increase in resources (Kingdon 2011). This seems extremely relevant for countries where defence faces a context of rationalisation. Failure to allocate sufficient resources will not only endanger current performance but will also negatively affect the development of new capabilities by limiting budgets for science and technology and the development of new defence capabilities for example (Perry 2013). 
The previous two paragraphs clearly illustrate how the DPMF unites and further strengthens the characteristics of existing frameworks, while mitigating many of the recorded challenges at the same time. Whereas mainstream PM practices are not always easily transferable to the public sector (Beeres, De Waard, and Bollen 2010; Keathley 2016), the DPMF significantly contributes to bridging this gap for defence organisations. Appendix two further summarises the previously described challenges identified in the literature along with any mitigating effect or action that can be linked to the DPMF.

\section{Practical implications and attention points for managers}

The previous sections clearly demonstrate that nations that are struggling to clearly articulate their strategy and to link this to an effective PM System should use the DPMF to strengthen their efforts. Whether used as a design or an assessment instrument, the DPFM provides decisionmakers a powerful and coherent framework that integrates the complex set of KPAs of defence organisations. In doing so, it supports the exploration and balance between performance optimisation of a specific KPA versus optimisation of the performance of the overall organisation.

Further, there is a need within NATO for additional risk monitoring tools and capabilities (Morgan 2015). Even if this is not the primary objective, the DPMF and strategy map can be used as a canvas for the collection and organisation of data for this purpose. Such tools facilitate strategy-formulation and decision-making (Morgan 2015), while also contributing to the 
enhancement of the overall organisational health and level of resilience (Xenidisa and Theocharous 2014).

However, regardless of the defence-specific focus and the comprehensive nature of the DPMF, it primarily aims to serve as a source of inspiration. As suggested by Chearskul (2010), Franco and Bourne (2003) and Martinez and Kennerley (2005), it remains important to take the specific organisational context into account when designing a PM System. So whether using the DPMF as an evaluation or a design instrument, further tailoring will be required to reflect the specific strategic context, choices, and terminology of a particular nation. This will avoid some of the same face-validity issues previously described. Despite a common rationale, defence efforts vary considerably from state to state (Norheim-Martinsen 2016; Lawrence and Jermalavičius 2012). Even within the same nation, strategy development needs vary considerably under different circumstances (Tama 2018), depending on the nation's specific interests and its overall security policy in general. For example, 'Mission outputs and effects' is a performance category that is well suited to illustrate the wide range of terminology and meanings for the same category within different nations. In effect, nations tend to use different definitions to describe what actually constitutes an operation, deployment or mission. While some countries consider deployments within their national borders as operations (e.g. ongoing anti-terror deployments in many western European countries), other nations may reserve such a qualification for interventions outside national borders only. Therefore, while the DPMF can serve as a wealthy source of inspiration, it is not a substitute for a carefully designed approach that continuously tunes the PM system to the evolving national environment, policy- and - strategic goals. 


\section{Conclusion}

While Performance Measurement (PM) Systems are associated with many strategic and organisation-wide benefits, strategic-level defence initiatives based on existing frameworks ${ }^{13}$ have suffered from a very low adoption rate (Cavoli 2004; Mol and Beeres 2005; Streit 2004). As a Systematic Literature Review indicated that most challenges were linked to PM System design, our study focused on the development of a new generic, comprehensive, and strategiclevel framework for designing and evaluating defence management and measurement efforts: The Defence Performance Measurement Framework or DPMF. The results of this study are based on a multinational and systematic comparison of defence management practice within twelve NATO countries. This is recognised as both unique and crucial, addressing a clear gap pertaining to the study of strategic-level defence managerial practices (Lawrence and Jermalavičius 2012; Norheim-Martinsen 2016).

The DPMF counters the challenges relating to the design of strategic-level PM Systems in defence, while simultaneously preserving the numerous benefits of existing frameworks. Similar to the Logic Model, it consists of three main perspectives: "ends", "ways", and "means". These perspectives contain seventeen categories and 77 underlying sub-categories in total. Each subcategory then contains a set of strategic objectives and eventual measures. The high number of KPAs retained as categories and sub-categories compared to the traditional frameworks better

\footnotetext{
${ }^{13}$ Such as the Balanced Scorecard (BSC) and the Logic Model.
} 
reflects the complexity and diversity of modern defence challenges as described by Chong (2015) and Posen (2016). The retained KPAs also allow the DPMF to preserve the different elements of balance that are described as crucial in the literature (Bourne et al. 2000; Kaplan and Norton 1992; Keathley 2016). This includes a balance ranging from “inputs" over "processes" towards "outputs", between tangible and intangible defence objectives, between efficiency- and effectiveness-related challenges, between short-term - and long-term strategies, and finally between policy "ends" and stakeholder contributions. In turn, the adoption of defence-specific terminology within the DPMF increases the legitimacy, buy-in, and face-validity of PM efforts for key internal and external stakeholders. Strategy mapping in particular increases the alignment between the PM System, defence policy, defence strategy, and strategic objectives. It allows decision-makers and stakeholders to visualise, contextualise, make sense of, and track organisational performance while assessing the impact of that performance over time, filling a gap previously identified by Morgan (2015).

In giving the organisational stakeholders due prominence ${ }^{14}$, the DPMF builds upon the need identified by Lindsay and Gartzke (2020) for new instruments that better conceptualize the complexity of interactions between resource constraints and critical processes on the one hand, and stakeholder expectations or policy "ends" on the other hand. In doing so, our research also responds to the need identified by Lawrence and Jermalavičius (2012) for integrated politico-

\footnotetext{
${ }^{14}$ In the PM literature, giving prominence and consideration to the different organisational stakeholders is a reflection of increased PM System maturity (Chearskul 2010; Wettstein and Kung 2002), and this is therefore also an important contribution of the DPMF.
} 
military decision-support and strategy-evaluation tools as a response to the environmental complexity of the current world. After all, it is in the civil-military stakeholder arena that the tasks, size, force structure, posture, and equipment acquisition are ultimately decided (Egnell 2016; Lindsay and Gartzke 2020). It follows that any strategic-level framework cannot claim to be truly comprehensive or strategic without being able to accommodate the high-level and consequential discussions pertaining to the important challenge nations are facing in bridging the gap between commitments and resources as described by Erbel (2017) and Tama (2018). As such, this endeavour to systematically integrate policy goals and stakeholder commitments provides a strong alternative for the mostly internally-focussed PM initiatives to date.

Ultimately, the better defence-specific design of the DPMF enables nations that are struggling with their defence strategy and strategic-level PM System to strengthen their efforts. When used as a design instrument, decision-makers can find inspiration from the DPMF and the long list of associated strategic objectives and metrics. When used as an evaluation instrument, the DPMF generates valuable insights with regard to policy development, strategy, ownership, maturity, and focus. In doing so, it helps in identifying blind spots ${ }^{15}$ and measurement gaps ${ }^{16}$. Following the evidence that better PM System design increases the likelihood of implementation and use (Arnold 2005; Keathley and Van Aken 2013), this work helps professionals and scholars address the implementation gap impacting the field. In turn, this should enable defence organisations to harness the reputed strategic and organisation-wide benefits well beyond reporting purposes, as

\footnotetext{
${ }^{15}$ Absence of KPAs or KPAs lacking focus in a nation's strategy.

${ }^{16}$ KPAs that are not measured.
} 
is presently often the case (Beeres, De Waard, and Bollen 2010; Beeres and Bogers 2011).

\section{Limitations and Future Research}

As previously discussed (and depicted in appendix two), one of the clear strengths of the DPMF is the inclusion of multiple stakeholder goals. However, it remains extremely difficult for defence organisations to manage the sometimes contradictory expectations of these numerous stakeholders. In effect, defence organisations are often only partly responsible for attaining policy objectives (Norheim-Martinsen 2016; Tama 2018; Tomlyn 2005). According to Marquis et al. (2006), three-quarters of governmental departments face challenges in agreeing what their joint outcomes are and how they can be attributed at the departmental level ${ }^{17}$. This has led to the debate as to whether joint outcomes should be measured at the departmental level at all, or, if they are cross-governmental in nature, a cross-governmental means of measurement should be implemented above the departmental PM Systems (Beeres and Van Fenema 2008; Marquis et al. 2006). As a result, additional research is needed to better understand the alignment of expectations and policy goals between cross-governmental stakeholders on the one hand, and defence strategy and performance on the other hand. Further, it remains challenging to develop and agree on objectives and measures in performance areas that are qualitative in nature such as operations and interoperability. Even if the DPMF features an enhanced characterisation of some these problematic areas, and can therefore go some way in supporting the development of new

\footnotetext{
${ }^{17}$ e.g. in this case the department of defence.
} 
quantitative measurement instruments, this remains an issue meriting further research as well.

Finally, this study was primarily concerned with design-related practices and challenges. Other critical factors such as the role of defence leadership during strategy development and strategic change (Chearskul 2010; Keathley, 2016) were not the focus of this study and therefore should be further investigated. Similarly, specific challenges defence organisations face during the other phases of the PM cycle, including PM System use and PM System review also merit additional research.

\section{Acknowledgements}

First, we would like to thank the national representatives who took part in the survey and meetings and thereby provided most of the data for this study. In particular, we would like to thank Mr. Tony Lawrence and Mr. Chad Young for their support in the development of the DPMF from the collected data. Their constant feedback proved to be invaluable for the development of the framework. Second, we would like to thank Mr Juan Raemdonck and Mr. Walter Baeten who delved on parts of the overall study within the context of their thesis and thereby facilitated the discovery of the potential of the framework. Finally, we acknowledge funding from the Royal High Institute for Defence (Belgium).

\section{Disclosure Statement}

No relevant financial benefit(s) or conflict of interest(s) to disclose 


\section{Biographical note about the authors}

Joaquim Soares is an officer in the Belgian Defence and a Joint PhD candidate at the University of Antwerp and the Royal Military Academy (RMA, Belgium) where he also serves as an assistant in the Department of Economics, Management and Leadership. Previously holding several management-related master's degrees, he has served as a supervisor for several Master thesis on this subject, has participated in several data collection and experimental studies, and has successfully completed his Joint PhD training. He is also an active participant in several NATO work-groups including SAS096 on Performance Management in Defence Organizations and SAS152 on Comprehensive National Defence Systems.

Geert Letens is a Colonel in the Department of Economics, Management and Leadership of the RMA and a research fellow at the Vlerick Business School. He has a M.S. in Telecommunications from the RMA, a M.S. in Mechatronics from KULeuven, and in TQM from Hasselt University. He holds a PhD in Applied Economics from Ghent University and in Social and Military Sciences from the RMA. Geert served as the President of the SEMS within IISE. He is a Fellow and past President of ASEM and serves as the voting member for Belgium on the NATO SAS panel.

Nathalie Vallet is a Professor at the University of Antwerp, Faculty of Applied Economics' Management department as well as the Faculty of Design Sciences of the same university. She currently serves as the vice-dean of this last faculty besides having other management and expert roles within the university. She teaches courses on general management, organization management and strategic management. Her current research focuses on strategic implementation and strategic management in the public sector. She is also specializes in qualitative research methods (grounded theory). She is also actively involved in the executive master's program in public management as well as the postgraduate program in social profit management of the Antwerp Management School. 
Wouter Van Bockhaven is a researcher and lecturer at the University of Antwerp, Faculty of Applied Economics' Management department. He received his PhD in Applied Economic Sciences from the University of Antwerp in 2014. His research focuses on how firms can develop innovation networks to tackle institutional and social barriers preventing the creation of shared value. He is engaged in teaching and coaching students in strategic analysis and consulting projects, strategic management, strategy implementation, PM and innovation management at various faculties of the University of Antwerp, the Antwerp Management School, the Royal Military Academy, the Artesis university college (Antwerp, Belgium) and the Karel De Grote university college (Antwerp, Belgium).

Heather Keathley-Herring is an Assistant Professor in the Industrial Engineering and Management Systems Department at the University of Central Florida. She received her Bachelor's degree in Systems Engineering from the University of Arkansas at Little Rock and her Master's degree in Industrial and Systems Engineering from Virginia Tech. She then completed a dual doctoral degree with the Grado Department of Industrial and Systems Engineering at Virginia Tech and the DEML department of the RMA in 2016. Her research is in Management Systems Engineering with a focus on organizational change and transformation. She is a member of Institute of Industrial and Systems Engineers and the American Society for Engineering Management.

Eileen Van Aken is a Professor and Interim Head of the Grado Department of Industrial and Systems Engineering at Virginia Tech. She is a three-time graduate of Virginia Tech, earning her B.S., M.S., and Ph.D. in industrial engineering in 1988, 1991, and 1995, respectively. Her research focuses on enterprise PM Systems, lean work systems, and organizational improvement practices. She is a Fellow of the Institute of Industrial and Systems Engineers (IISE), the American Society for Engineering Management, and the World Academy of Productivity Sciences. She is also a member of both the American Society for Quality and the American Society for Engineering Education. 


\section{Cited References}

Arnold, Ronald. 2005. "Performance Metrics for the Program Executive Office for Integrated Warfare Systems 1.0 and 2.0.” Naval Postgraduate School.

Band, Jonathan. 2004. "Performance Management in a Volatile Environment." The RUSI Journal 149 (1): 48-51

Bayne, Jay, and Paul Raymond. 2003. "Performance Measurement in C2 Systems." Defence University Defence Technical Information Center.

Beeres, Robert, and Marion Bogers. 2011. "Ranking the Performance of European Armed Forces.", Defence and Peace Economics 23 (1): 1-16

Beeres, Robert, Erik De Waard, and Myriame Bollen. 2010. “Ambitions and Opportunities for Assessing Military Performance in Crisis Response Operations." Financial Accountability and Management 26 (3): 344-366

Beeres, Robert, and Paul van Fenema. 2008. "Assessing Civil-Military Performance: Toward a Research Agenda." Chapter in Managing Civil-military Cooperation, edited by Myriame Bollen and Sebastiaan Rietjens, 167-178. The Netherlands: Routledge.

Boynton, Robert, and Larry Vaughan. 1998. "Defining Organisational Measures for NAESU." Naval Postgraduate School.

Bourne, Mike, Mike Kennerley, and Monica Franco-Santos. 2005. "Managing through Measures: A Study of Impact on Performance." Journal of Manufacturing Technology Management 16 (4): 373-395.

Bourne, Mike, John Mills, Mark Wilcox, Andy Neely, and Kenn Platts. 2000. "Designing, Implementing and Updating Performance Measurement Systems." International Journal of Operations and Production Management 20 (7): 754-771.

Bourne, Mike, Andy Neely, Kenn Platts, and John Mills. 2002. "The Success and Failure of Performance Measurement Initiatives." International Journal of Operations and Production Management 22 (11): 1288-1310. DOI 10.1108/01443570210450329.

Bourne, Pippa, and Mike Bourne. 2005. "Views from around the World." Measuring Business Excellence 9 (3). 
Braun, Virginia, and Victoria Clarke. 2006. "Using Thematic Analysis in Psychology." Qualitative Research in Psychology 3 (2): 77-101.

Bush, Patricia. 2005. "Strategic Performance Management in Government: Using the BSC." Journal of Cost Management 19 (3): 24-31.

Cavoli, Christina. 2004. "The Balanced Scorecard and other Thoughts on Metrics." Defence and AT-l 33 (1): 9-11.

Chearskul, Pimsinee. 2010. “An Empirical Investigation of Performance Measurement System Use and Organisational Performance." PhD diss., Virginia Tech.

Chesley, Julie, and Mike Wenger. 1999. "Transforming an Organisation: Using Models to Foster a Strategic Conversation.” California Management Review 41 (3): 54-73.

Christiaens, Johan, Aime Heene, and Christophe Vanhee. 2009. "Onderzoeksopdracht: Het Bepalen van Relevante Prestatie-Indicatoren in de Centra voor Teleonthaal en de Centra voor Integrale Gezinszorg in het Kader van de Opmaak van een Vereinigingsdossier."

Chong, Alan. 2015. "Smart Power and Military Force: An Introduction." Journal of Strategic Studies 38 (3): 233-244. DOI: 10.1080/01402390.2014.1002915.

Creswell, John. 2003. Research Design: Qualitative, Quantitative, and Mixed Method Approaches. Thousand Oaks: Sage.

Davis, Paul. 2018. "Defense Planning when Major Changes are Needed.” Defence Studies 18 (3): 374-390. DOI: 10.1080/14702436.2018.1497444.

de Waal, Andre. 2002. "The Power of World-Class Performance Management: Use It!" Measuring Business Excellence 6 (3): 9-19.

de Waal, Andre, Karima Kourtit, and Peter Nijkamp. 2009. "The Relationship between the Level of Completeness of a Strategic Performance Management System and Perceived Advantages and Disadvantages." International Journal of Operations and Production Management 29 (12): 1242-1265.

Dwyer, Daniel, Oser Randall, Eduardo Salas, and Jennifer Fowlkes. 1999. "PM in Distributed Environments: Initial Results and Implications for Training." Military Psychology 11 (2): 189-215.

Edmunds, Timothy, Antonia Dawes, Paul Higate, Neil Jenkings, and Rachel Woodward. 2016. "Reserve Forces and the Transformation of British Military Organisation: Soldiers, 
Citizens and Society.” Defence Studies 16 (2): 118-136. DOI:

$10.1080 / 14702436.2016 .1163225$.

Egnell, Robert. 2006."Explaining US and British Performance in Complex Expeditionary Operations: The Civil-Military Dimension.” Journal of Strategic Studies 29 (6): 10411075. DOI: $10.1080 / 01402390601016717$.

Eisenhardt, Kathleen, and Melissa Graebner. 2007. “Theory Building from Cases: Opportunities and Challenges." The Academy of Management Journal 50 (1): 25-32.

Erbel, Mark. 2017. "The Underlying Causes of Military Outsourcing in the USA and UK: Bridging the Persistent Gap between Ends, Ways and Means since the Beginning of the Cold War.” Defence Studies 17 (2): 135-155. DOI: 10.1080/14702436.2017.1294970.

Folan, Paul, and Jim Browne. 2005. "A Review of Performance Measurement: Towards Performance Management." Computers in Industry 56 (7): 663-680.

Franco, Monica, and Mike Bourne. 2003. "Factors that Play a Role in 'Managing through Measures." Management Decision 41 (8): 698-710.

Golafshani, Nahid. 2003. "Understanding Reliability and Validity in Qualitative Research." The Qualitative Report 8 (4): 597-606.

Goldman, Emily. 2004. "Introduction: Information Resources and Military Performance." Journal of Strategic Studies 27 (2): 195-219. DOI: 10.1080/0140239042000255896.

Hackleman, Andrew, Alan Johnson, and Darryl Ahner. 2014. "Nuclear Enterprise Performance Measurement" The Journal of Defence Modelling and Simulation 11 (3): 245-264.

Hepler, Aaron. 2008. "Balanced Scorecard: Evaluation of Air Force Materiel Command's Implementation and Use." Air Force Institute of Technology.

Hill, William. 1974. "The Development of Performance Measurement Systems Used by the Department of Defence: C/SCSC and its Forerunners.” Pacific Lutheran University Tacoma.

Huntington, Samuel. 1981. The Soldier and the State: The Theory and Politics of Civil-military Relations. Cambridge, MA: Harvard University Press.

Ittner, Christopher, and David Larcker. 2003. "Coming up Short on Nonfinancial Performance Measurement." Harvard Business Review 81 (11): 88-95. 
Ivancík, Radoslav, and Pavel Necas. 2012. "System of Balanced Scorecard and its Implementation in Management of Norwegian Air Force and other Military Organisations." Incas Bulletin 4 (4): 141-150.

Jensen, Benjamin. 2018. "The Role of Ideas in Defense Planning: Revisiting the Revolution in Military Affairs." Defence Studies 18 (3): 302-317. DOI: $10.1080 / 14702436.2018 .1497928$.

Kaplan, Robert, and David Norton. 1992. "The Balanced Scorecard - Measures that Drive Performance." Harvard Business Review 83 (7): 71-79.

Kaplan, Robert, and David Norton. 2004. Strategy Maps: Converting Intangible Assets into Tangible Outcomes. Cambridge, MA: Harvard Business School Publishing Corporation.

Keathley, Heather. 2016. "Empirical Investigation of Factors that Affect the Successful Implementation of Performance Measurement Systems." Virginia Tech.

Keathley, Heather, Runsheng Du, and Kelly Olliges. 2015. "Review of Performance Measurement Practices in Military and Government Sectors." Paper presented at the annual conference of the Institute of Industrial and Systems Engineers, Nashville, May 30- June.

Keathley, Heather, and Eileen Van Aken. 2013. "Systematic Literature Review on the Factors that Affect Performance Measurement System Implementation.” Paper presented at annual conference of the Institute of Industrial and Systems Engineers, San Juan, May $18-22$.

Kem, Dale, Bobby Jackson, Avery Williams, and Virginia Stouffer. 2000. "Performance Metrics for Defence Working Capital Funds, A Focus on Supply Management." Logistics Management Institute.

Kingdon, Brigadier. 2011. "In an Era that Demands Multilateral Responses to External Threats, Does the UK Have the Capacity for Independent Strategic Design and Action?" Defence Studies 11 (3): 396-419. DOI: 10.1080/14702436.2011.630174.

Lassen, Gregg. 2010. "Adaptation of Balanced Scorecard and Multiple Criteria Decision-Making Methodologies to Measure Nation-State Power." PhD diss. The University of Southern Mississippi. 
Lawrence, Tony, and Tomas Jermalavičius. 2012. "Fit for Purpose: How Should the Higher Levels of Defence Be Organised in the Contemporary Strategic Environment?" Defence Studies 12 (4): 503-522. DOI: 10.1080/14702436.2012.745963.

Levene, Peter. 2013. "Defence Reform: An Independent Report into the Structure and Management of the Ministry of Defence." Ministry of Defence.

Lindsay, Jon, and Erik Gartzke. 2020. "Politics by many other Means: The Comparative Strategic Advantages of Operational Domains." Journal of Strategic Studies. DOI: $10.1080 / 01402390.2020 .1768372$.

MacBryde, Jill, Steve Paton, Neil Grant, and Margaret Bayliss. 2012. "Performance Measurement Driving Change: A Case from the Defence Sector." International Journal of Productivity and Performance Management 61 (5): 462-482.

Marin, Jean-Charles. 2012. "The Impact of Strategic Planning and the Balanced Scorecard Methodology on Middle Managers Performance in the Public Sector." International Journal of Business and Social Science 3 (1): 114-127.

Marquis, Jefferson, Richard Darilek, Jason Castillo, Cathryn Thurston, Anny Wong, Cynthia Huger, Andrea Mejia, Jennifer Moroney, Brian Nichiporuk and Brett Steele. 2006. "Assessing the Value of US Army International Activities." Rand Corporation.

Martinez, Veronica, and Mike Kennerley. 2005. "Performance Measurement Systems: Benefits." Paper presented at the EURAM Annual Conference, Munich, May 4-7.

Mol, Nico, and Robert Beeres. "Performance Management in a Setting of Deficient Output Controls." International Journal of Productivity and Performance Management 54 (7): 533-550.

Monetta, Dominic, and Myron Holmes. 1989. "Performance Measurement in the Navy Industrial Fund Ordnance Community.” Naval Ordnance Station Indian Head.

Morgan, Matthew. 2015. "Strategy in Flux: NATO's Adoption of Risk Management and the Elaboration of a New Framework of Command and Control." Defence Studies 15 (1): 114. DOI: $10.1080 / 14702436.2014 .999475$.

Morgan, Patrick. 2003. "NATO and European Security: The Creative use of an International Organization.” Journal of Strategic Studies 26 (3): 49-74. DOI: 10.1080/01402390412331303055. 
Norheim-Martinsen, Per. 2016. "New Sources of Military Change - Armed Forces as Normal Organizations.” Defence Studies 16 (3): 312-326. DOI: 10.1080/14702436.2016.1195234.

NATO (North Atlantic Treaty Organisation). 2011. "Defence Measurements: A Composite Metric Approach”. Joint Analysis and Lessons Learned Centre.

NATO (North Atlantic Treaty Organisation). 2020. "Performance Management in Defence Organisations". NATO Science and Technology Organisation.

Neely, Andy, Mike Gregory and Ken Platts. 1995. "Performance Measurement System Design: A Literature Review and Research Agenda.” International Journal of Operations and Production Management 15 (4): 80-116.

Neely, Andy, Chris Adams and Paul Crowe. 2001. "The Performance Prism in Practice." Measuring Business Excellence 5 (2): 6-13.

Neely, Andy, and Yasar Jarrar. 2004. "Extracting Value from Data - The Performance Planning Value Chain.” Business Process Management Journal 10 (5): 506-509.

Nudurupati, Sai, Umit Bititci, Vikas Kumar and Felix Chan. "State of the Art Literature Review on Performance Measurement." Computers and Industrial Engineering 60 (2): 279-290.

Ong, Gerard. 2003. “Credibility Over Courage: NATO's Mis-Intervention in Kosovo.” Journal of Strategic Studies 26 (1): 73-108. DOI: 10.1080/01402390308559309.

Perry, David. 2013. "A Return to Realism: Canadian Defence Policy after the Great Recession.” Defence Studies 13 (3): 338-360. DOI: 10.1080/14702436.2013.845386.

Porter, Wayne, and Mark Mykleby. 2012. "Rethinking America's Joint Force: Strength and Credibility in a Constrained Fiscal Environment." American Foreign Policy Interests 34 (2): 57-68.

Posen, Barry. 2016. "Foreword: Military Doctrine and the Management of Uncertainty." Journal of Strategic Studies 39 (2): 159-173. DOI: 10.1080/01402390.2015.1115042.

Saxi, Håkon. 2017. "British and German Initiatives for Defence Cooperation: the Joint Expeditionary Force and the Framework Nations Concept.” Defence Studies 17 (2): 171 197. DOI: 10.1080/14702436.2017.1307690.

Sauer, Tom. 2015. "Deep Cooperation by Belgian Defence: Absorbing the Impact of Declining Defence Budgets on National Capabilities.” Defence Studies 15 (1): 46-62. DOI: 10.1080/14702436.2015.1005900. 
Schriver, Karan. 2000. "Strategic and Performance Plans for Shore Installations.” Naval Postgraduate School.

Sedosheva, Maritana. 2011. "The Balanced Scorecard and the New IT Approach to the Defence Budgeting Process." EBS Review 28.

Stevens, James. 2004. "The Balanced Scorecard and Army Strategic Readiness System." Army A- $L$ 40-45.

Streit, Phillip. 2004. "DoD Financial Indicators: DoD Financial Management Balanced Scorecard. " Armed Forces Comptroller: 40-42.

Tama, Jordan. 2018. “Tradeoffs in Defense Strategic Planning: Lessons from the U.S. Quadrennial Defense Review.” Defence Studies 18(3): 279-301. DOI: 10.1080/14702436.2018.1497442.

Tardy, Thierry. 2014. "The Reluctant Peacekeeper: France and the Use of Force in Peace Operations." Journal of Strategic Studies 37 (5): 770-792. DOI: 10.1080/01402390.2014.905472.

Taticchi, Paolo, Flavio Tonelli, and Luca Cagnazzo. 2010. "Performance Measurement and Management: A Literature Review and a Research Agenda." Measuring Business Excellence 14 (1): 4-18.

Tomlyn, H. 2005. "Can the Current Ministry of Defence Performance Management Regime Cope with Cognitive Effects?" Defence Studies 5 (3): 323-345.

Waggoner, Daniel, Andy Neely, and Mike Kennerley. 1999. "The Forces that Shape Organisational Performance Measurement Systems: An Interdisciplinary Review.” International Journal of Production Economics 60: 53-60.

Webb, Nathalie, and Philip Candreva. 2010. "Diagnosing Performance Management and Performance Budgeting Systems: A Case Study of the US Navy." Public Finance and Management 10 (3): 524-555.

Wettstein, Thomas, and Peter Kung. 2002. "A Maturity Model for Performance Measurement Systems." Management Information Systems 26: 113-122.

Woodley, Philip. 2002. "Ship shape." Financial Management 30

Xenidis, Yiannis, and Kyriakos Theocharous. 2014. "Organisational Health: Definition and Assessment." Procedia Engineering 85: 562-570. 
Appendix one. Final Code Structure Reflecting Categories and Sub-categories

\begin{tabular}{|c|c|}
\hline International Credibility & National Credibility \\
\hline $\begin{array}{l}\text { National credibility and reputation pertaining to } \\
\text { NATO and EU }\end{array}$ & Public support for defence \\
\hline $\begin{array}{l}\text { General international credibility and reputation } \\
\text { that is not specific to NATO and EU }\end{array}$ & Social and environmental responsibility \\
\hline $\begin{array}{l}\text { Multi-lateral diplomacy, treaties, and other } \\
\text { engagements with foreign defence organisations }\end{array}$ & $\begin{array}{l}\text { Strategic communication and reporting to } \\
\text { parliament, politicians, and public }\end{array}$ \\
\hline $\begin{array}{l}\text { National Interests and Defence \& Security } \\
\text { Needs }\end{array}$ & $\begin{array}{l}\text { Alignment of defence with national } \\
\text { Government leadership }\end{array}$ \\
\hline $\begin{array}{l}\text { Protect national sovereignty, territorial integrity, } \\
\text { and national way-of-life }\end{array}$ & Ready Force Elements \\
\hline $\begin{array}{l}\text { Contribute to the achievement of overarching } \\
\text { national interests and level of ambition }\end{array}$ & General and mission-specific readiness \\
\hline $\begin{array}{l}\text { Provide continental defence, international } \\
\text { stabilisation, and support to allies }\end{array}$ & $\begin{array}{l}\text { Alliance specific readiness obligations and } \\
\text { commitments }\end{array}$ \\
\hline Protect against terrorism (foreign and domestic) & $\begin{array}{l}\text { Contribution of reserve forces (may include } \\
\text { temporary conscripts) }\end{array}$ \\
\hline $\begin{array}{l}\text { Provide security via anti-proliferation and } \\
\text { disarmament }\end{array}$ & Pre-positioning \\
\hline $\begin{array}{l}\text { Provide security by ensuring human safety and } \\
\text { emergency response }\end{array}$ & \\
\hline
\end{tabular}




\begin{tabular}{|c|c|}
\hline $\begin{array}{l}\text { Facilitate the attainment of particular political } \\
\text { interests }\end{array}$ & Mission Outputs and Effects \\
\hline $\begin{array}{l}\text { Provide social relevance to the citizens of the } \\
\text { nation }\end{array}$ & $\begin{array}{l}\text { Defence services and defence collaborations } \\
\text { with other governmental organisations }\end{array}$ \\
\hline $\begin{array}{l}\text { Facilitate the enforcement of national and } \\
\text { international laws }\end{array}$ & $\begin{array}{l}\text { Military operations and standing defence } \\
\text { tasks }\end{array}$ \\
\hline $\begin{array}{l}\text { Facilitate the attainment of particular economic } \\
\text { interests }\end{array}$ & $\begin{array}{l}\text { Ongoing command, control, and } \\
\text { coordination of defence tasks }\end{array}$ \\
\hline $\begin{array}{c}\text { Capability Development and Integration } \\
\text { Initiatives }\end{array}$ & $\begin{array}{l}\text { Transformation and Continuous } \\
\text { Improvement Initiatives }\end{array}$ \\
\hline $\begin{array}{l}\text { Specific areas of focus for developing national } \\
\text { capabilities }\end{array}$ & National transformation initiatives \\
\hline $\begin{array}{l}\text { Establishment of priorities and scenario-based } \\
\text { planning }\end{array}$ & $\begin{array}{l}\text { Overarching efficiency, cost reduction, and } \\
\text { mandate rationalisation initiatives }\end{array}$ \\
\hline $\begin{array}{l}\text { Capabilities design, capability management, and } \\
\text { integrating the fundamental elements of } \\
\text { capability }\end{array}$ & Focused improvement initiatives \\
\hline Operational experiences and lessons learned & Alliance transformation \\
\hline $\begin{array}{l}\text { Capability sufficiency analysis and integrated } \\
\text { capability planning }\end{array}$ & $\begin{array}{c}\text { Military Collaboration and Ensuring } \\
\text { Interoperability with Allies }\end{array}$ \\
\hline \multirow[t]{2}{*}{ Concepts, doctrine, and experimentation } & Interoperability improvements \\
\hline & Common weapon programs \\
\hline
\end{tabular}




\begin{tabular}{|c|c|}
\hline $\begin{array}{c}\text { Overarching C2 Processes and Supporting } \\
\text { Services }\end{array}$ & Integration within multinational coalitions \\
\hline Performance management and reporting & Multinational training \\
\hline Risk and consequence management & $\begin{array}{c}\text { Force Structure Production and Renewal } \\
\text { Processes }\end{array}$ \\
\hline Strategic management practice & $\begin{array}{l}\text { Adequacy and balance in the force structure } \\
\text { and force posture }\end{array}$ \\
\hline Internal auditing & Production and renewal of the force \\
\hline Support services & Readiness-related training \\
\hline Inventories of Equipment & Science, Technology, and Knowledge \\
\hline $\begin{array}{l}\text { Material availability, readiness, and } \\
\text { contingency for operations }\end{array}$ & $\begin{array}{l}\text { Identification and development of defence } \\
\text { science and technologies }\end{array}$ \\
\hline $\begin{array}{l}\text { The overarching management of equipment } \\
\text { programs and portfolios }\end{array}$ & $\begin{array}{l}\text { Collaboration with industry with regard to } \\
\text { science and technology }\end{array}$ \\
\hline $\begin{array}{l}\text { The execution of materiel acquisition and } \\
\text { procurement }\end{array}$ & Personnel, Organisation, and Culture \\
\hline $\begin{array}{l}\text { The execution of ongoing materiel maintenance, } \\
\text { testing, upgrade, and divestment }\end{array}$ & $\begin{array}{l}\text { The management of manning, } \\
\text { organisational structure, and personnel } \\
\text { readiness }\end{array}$ \\
\hline Equipment-specific policy and strategy & $\begin{array}{l}\text { Care, support, and morale of defence } \\
\text { personnel }\end{array}$ \\
\hline Infrastructure Assets & Recruitment and selection \\
\hline
\end{tabular}




\begin{tabular}{|c|c|}
\hline $\begin{array}{l}\text { Availability of infrastructure and infrastructure } \\
\text { expertise in accordance with operational } \\
\text { requirements }\end{array}$ & Job attractiveness \\
\hline $\begin{array}{l}\text { Infrastructure acquisition, construction, and } \\
\text { improvement }\end{array}$ & $\begin{array}{l}\text { Career planning, individual education, and } \\
\text { professional development }\end{array}$ \\
\hline $\begin{array}{l}\text { Infrastructure and real estate portfolio } \\
\text { management }\end{array}$ & $\begin{array}{l}\text { Management of retention, transition, } \\
\text { attrition, and departure }\end{array}$ \\
\hline Infrastructure divestment and disposal & Working conditions \\
\hline Environment & Management of the reserve force \\
\hline Inventories of Information Systems & Defence and Security Budgets \\
\hline Strategic information system initiatives & Budget allocation and expenditure control \\
\hline Management of information systems portfolios & $\begin{array}{l}\text { Levels of fiscal appropriation from the } \\
\text { national Government for purposes of } \\
\text { national defence }\end{array}$ \\
\hline $\begin{array}{l}\text { Ongoing information systems acquisition, } \\
\text { deployment, security, user support, and } \\
\text { divestment }\end{array}$ & $\begin{array}{l}\text { The relative balance in the allocation of } \\
\text { fiscal resources across budget partitions }\end{array}$ \\
\hline Information and Intelligence & Funding provided to international alliances \\
\hline $\begin{array}{l}\text { Knowledge, intelligence, foresight, and } \\
\text { anticipation }\end{array}$ & Financial arrangements \\
\hline $\begin{array}{l}\text { Intelligence preparation, organisation, } \\
\text { procedures, and adaptation }\end{array}$ & $\begin{array}{l}\text { The relative balance in the allocation of } \\
\text { fiscal resources across defence programs }\end{array}$ \\
\hline
\end{tabular}


Appendix two. Mapping the DPMF vs. Recorded Challenges

\begin{tabular}{|c|c|c|c|}
\hline $\begin{array}{l}\text { Type of } \\
\text { challenge }\end{array}$ & Reference & Challenge or Gap & $\begin{array}{l}\text { DPMF linked remedy, } \\
\text { approach or suggestion }\end{array}$ \\
\hline Defence-specific & $\begin{array}{l}\text { (Keathley, Du, } \\
\text { and Olliges } \\
\text { 2015) }\end{array}$ & $\begin{array}{l}\text { The lack of focus on } \\
\text { strategic goals, but } \\
\text { rather a collection of } \\
\text { tactical and operational } \\
\text { performance from } \\
\text { departments or lower } \\
\text { organisational levels }\end{array}$ & $\begin{array}{l}\text { The DPMF unites KPAs } \\
\text { and underlying objectives } \\
\text { that solely focus on policy } \\
\text { and the strategic-level }\end{array}$ \\
\hline Defence-specific & $\begin{array}{l}\text { (Beeres, De } \\
\text { Waard, and } \\
\text { Bollen 2010; Mol } \\
\text { and Beeres 2005; } \\
\text { Marin 2012; } \\
\text { Monetta and } \\
\text { Holmes 1989) }\end{array}$ & $\begin{array}{l}\text { The lack of balance in } \\
\text { military PM Systems: } \\
\text { too much focus on } \\
\text { measurements of inputs }\end{array}$ & $\begin{array}{l}\text { The DPMF is a holistic and } \\
\text { comprehensive framework } \\
\text { built on a broad spectrum of } \\
\text { strategic goals of twelve } \\
\text { nations. It reflects adequate } \\
\text { balance between inputs, } \\
\text { processes and outputs }\end{array}$ \\
\hline Defence-specific & $\begin{array}{l}\text { (Kingdon 2011; } \\
\text { Taticchi, Tonelli, } \\
\text { and Cagnazzo } \\
\text { 2010) }\end{array}$ & $\begin{array}{l}\text { The lack of face- } \\
\text { validity of traditional } \\
\text { frameworks (e.g. BSC, } \\
\text { Performance Prism) in a } \\
\text { defence context }\end{array}$ & $\begin{array}{l}\text { Face-validity is assured } \\
\text { through the fit with core- } \\
\text { business activities of } \\
\text { defence and through the } \\
\text { explicit use of defence } \\
\text { terminology }\end{array}$ \\
\hline
\end{tabular}




\begin{tabular}{|c|c|c|c|}
\hline & & & $\begin{array}{l}\text { The use of the "means"- } \\
\text { "ways"-"ends" structure as } \\
\text { well as the incorporation of } \\
\text { DOTPMLPFI elements } \\
\text { further increase face- } \\
\text { validity since they are } \\
\text { extensively used within } \\
\text { NATO capability planning } \\
\text { efforts }\end{array}$ \\
\hline Defence-specific & $\begin{array}{l}\text { (Beeres and } \\
\text { Bogers 2011; } \\
\text { Tardy 2014; } \\
\text { Tomlyn 2005) }\end{array}$ & $\begin{array}{l}\text { The focus of traditional } \\
\text { frameworks lies on } \\
\text { efficiency whereas } \\
\text { defence decision-makers } \\
\text { may be more worried } \\
\text { about effectiveness }\end{array}$ & $\begin{array}{l}\text { The DPFM reflects both a } \\
\text { productivity and an } \\
\text { innovation strategy. This } \\
\text { assures equal attention on } \\
\text { effectiveness and } \\
\text { efficiency }\end{array}$ \\
\hline $\begin{array}{l}\text { Defence- } \\
\text { enhanced }\end{array}$ & $\begin{array}{c}\text { (Beeres and } \\
\text { Bogers 2011; } \\
\text { Bourne, } \\
\text { Kennerley, and } \\
\text { Franco-Santos } \\
\text { 2005; Cavoli } \\
\text { 2004; Dwyer et }\end{array}$ & $\begin{array}{l}\text { The failure of traditional } \\
\text { and highly consolidated } \\
\text { frameworks to reflect } \\
\text { the diversity and } \\
\text { complexity of a nation's } \\
\text { defence organisation }\end{array}$ & $\begin{array}{l}\text { Through the identification } \\
\text { of seventeen KPAs, the } \\
\text { DPMF has a low degree of } \\
\text { consolidation. With its } \\
\text { focus on } \\
\text { comprehensiveness, it }\end{array}$ \\
\hline
\end{tabular}




\begin{tabular}{|c|c|c|c|}
\hline & $\begin{array}{c}\text { al. 1999; } \\
\text { Nudurupati et al. } \\
\text { 2011; Marquis et } \\
\text { al. 2006) }\end{array}$ & & $\begin{array}{l}\text { better reflects defence } \\
\text { diversity and complexity }\end{array}$ \\
\hline $\begin{array}{l}\text { Defence- } \\
\text { enhanced }\end{array}$ & $\begin{array}{l}\text { (Chearskul 2010; } \\
\text { Bourne et al. } \\
\text { 2000; Hepler } \\
\text { 2008; Ittner and } \\
\text { Larcker 2003; } \\
\text { Ivancik and } \\
\text { Necas 2012; } \\
\text { Kaplan and } \\
\text { Norton 2004; } \\
\text { Neely and Jarrar } \\
\text { 2004; Sedosheva } \\
\text { 2011) }\end{array}$ & $\begin{array}{l}\text { The failure to } \\
\text { conceptualise } \\
\text { relationships between } \\
\text { critical (defence) } \\
\text { information in terms of } \\
\text { a visual tool directly } \\
\text { connecting the PM } \\
\text { System to the defence } \\
\text { strategy } \\
\text { The lack of alignment } \\
\text { between the PM System, } \\
\text { defence policy goals, } \\
\text { defence strategy, } \\
\text { organisational } \\
\text { objectives, and } \\
\text { measures }\end{array}$ & $\begin{array}{l}\text { The concurrent } \\
\text { development of the DPMF } \\
\text { (and its potential to serve) } \\
\text { as a strategy map based on } \\
\text { defence policy and defence } \\
\text { strategy documents along } \\
\text { with a long list of } \\
\text { objectives and measures } \\
\text { mitigates this challenge }\end{array}$ \\
\hline $\begin{array}{l}\text { Defence- } \\
\text { enhanced }\end{array}$ & $\begin{array}{l}\text { (Bourne et al. } \\
\text { 2002; Chesley }\end{array}$ & $\begin{array}{c}\text { There are difficulties in } \\
\text { identifying the }\end{array}$ & $\begin{array}{l}\text { The DPMF incorporates } \\
\text { several stakeholder- }\end{array}$ \\
\hline
\end{tabular}




\begin{tabular}{|c|c|c|c|}
\hline & $\begin{array}{c}\text { and Wenger } \\
\text { 1999; Kaplan and } \\
\text { Norton 2004; } \\
\text { Marquis et al. } \\
\text { 2006; Ong 2003; } \\
\text { Sedosheva 2011) }\end{array}$ & $\begin{array}{c}\text { customers or the } \\
\text { stakeholders } \\
\text { There are difficulties in } \\
\text { tailoring different types } \\
\text { of objectives for } \\
\text { different stakeholders }\end{array}$ & $\begin{array}{l}\text { focused categories and } \\
\text { sub-categories, facilitating } \\
\text { a discussion on both their } \\
\text { expectations and their } \\
\text { contributions. In doing so, } \\
\text { the DPMF features an } \\
\text { enhanced integration of } \\
\text { stakeholders comparted to } \\
\text { other traditional } \\
\text { frameworks }\end{array}$ \\
\hline $\begin{array}{l}\text { Defence- } \\
\text { enhanced }\end{array}$ & $\begin{array}{l}\text { (Beeres and } \\
\text { Bogers 2011; } \\
\text { Bourne et al. } \\
\text { 2002; } \\
\text { Christiaens, } \\
\text { Heene, and } \\
\text { Vanhee 2009; } \\
\text { Kaplan and } \\
\text { Norton 2004; } \\
\text { Keathley 2016; } \\
\text { Marquis et al. } \\
\text { 2006; Marin } \\
\text { 2012; Monetta }\end{array}$ & $\begin{array}{l}\text { It is challenging to } \\
\text { quantify some of the } \\
\text { critical outputs of } \\
\text { defence organisations in } \\
\text { areas that are more } \\
\text { qualitative in nature }\end{array}$ & $\begin{array}{l}\text { This challenge is sustained. } \\
\text { However, the DPMF } \\
\text { features an enhanced } \\
\text { characterisation of some of } \\
\text { the problematic areas such } \\
\text { as science and technology, } \\
\text { mission outputs and } \\
\text { effects, and } \\
\text { interoperability which can } \\
\text { support the development of } \\
\text { new evaluation and control } \\
\text { instruments }\end{array}$ \\
\hline
\end{tabular}




\begin{tabular}{|c|c|c|c|}
\hline & and Holmes & & \\
& $1989)$ & & \\
\hline
\end{tabular}


Table I. The Framework Development Process, adapted from Braun and Clarke (2006)

\begin{tabular}{|l|l|l|}
\hline \multicolumn{3}{|c|}{ Framework Development Process } \\
\hline 1 & $\begin{array}{l}\text { Frocess } \\
\text { responses to open questions }\end{array}$ & Result \\
\hline 2 & $\begin{array}{l}\text { Generation of initial codes - based } \\
\text { on analysis of additional documents } \\
\text { provided by nations }\end{array}$ & Concept maps \\
\hline 3 & $\begin{array}{l}\text { Searching for themes among codes } \\
- \text { preliminary analysis }\end{array}$ & Initial definition of dominant \\
\hline 4 & $\begin{array}{l}\text { Reviewing categories - detailed } \\
\text { analysis of documents of most } \\
\text { mature nations }\end{array}$ & Strategy maps for the two most mature \\
\hline 5 & nefining and naming of categories & Definitions of the categories and \\
\hline 5 & enumeration of underlying sub-categories \\
\hline
\end{tabular}


Figure 1. Illustration of Phase 2: Concept Map for a Participating Nation ${ }^{18}$

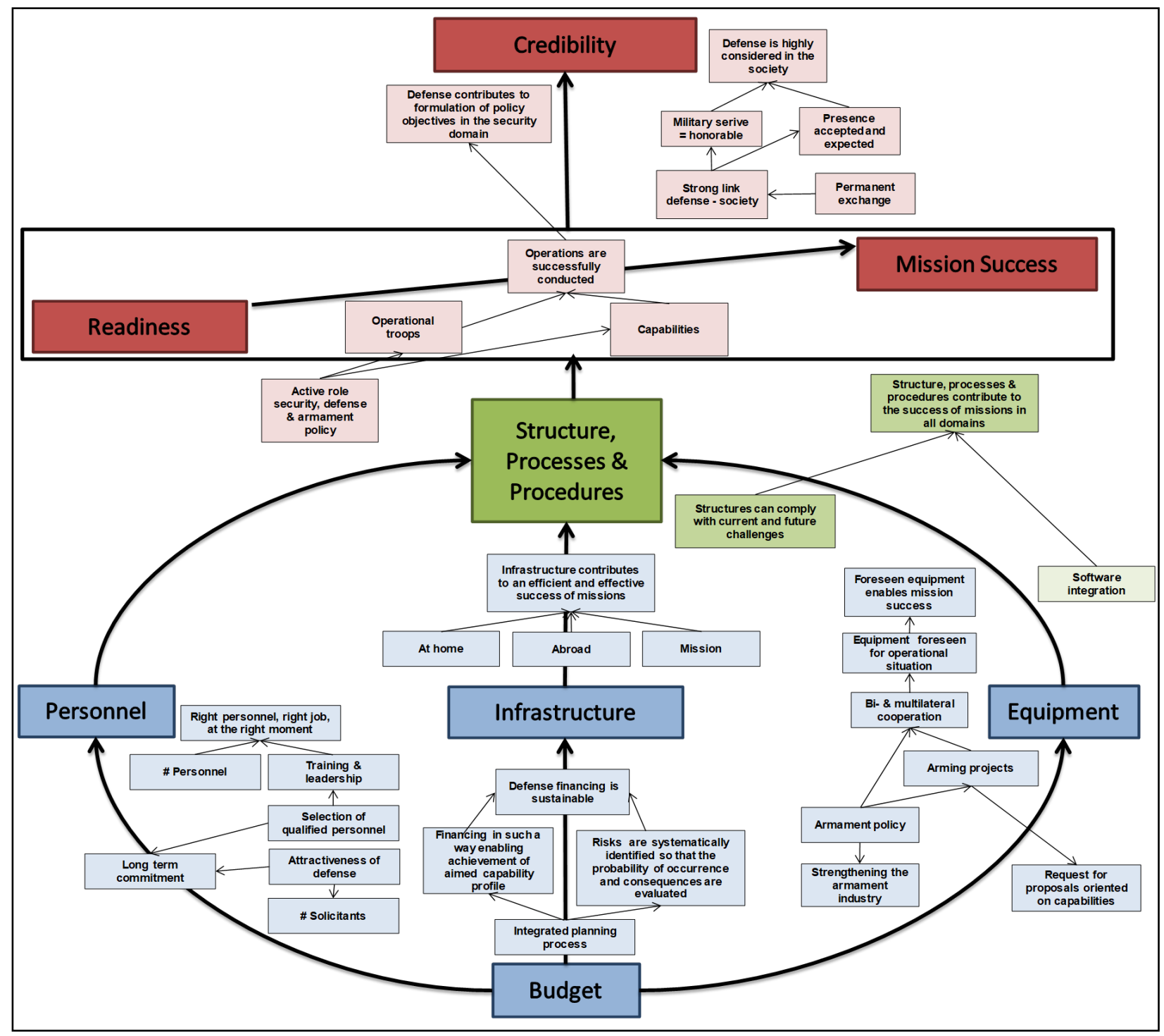

${ }^{18}$ The Figure deliberately avoids presenting some details to preserve the national anonymity 
Figure 2. The Generic, Comprehensive, and Strategic-Level Defence Performance Measurement Framework

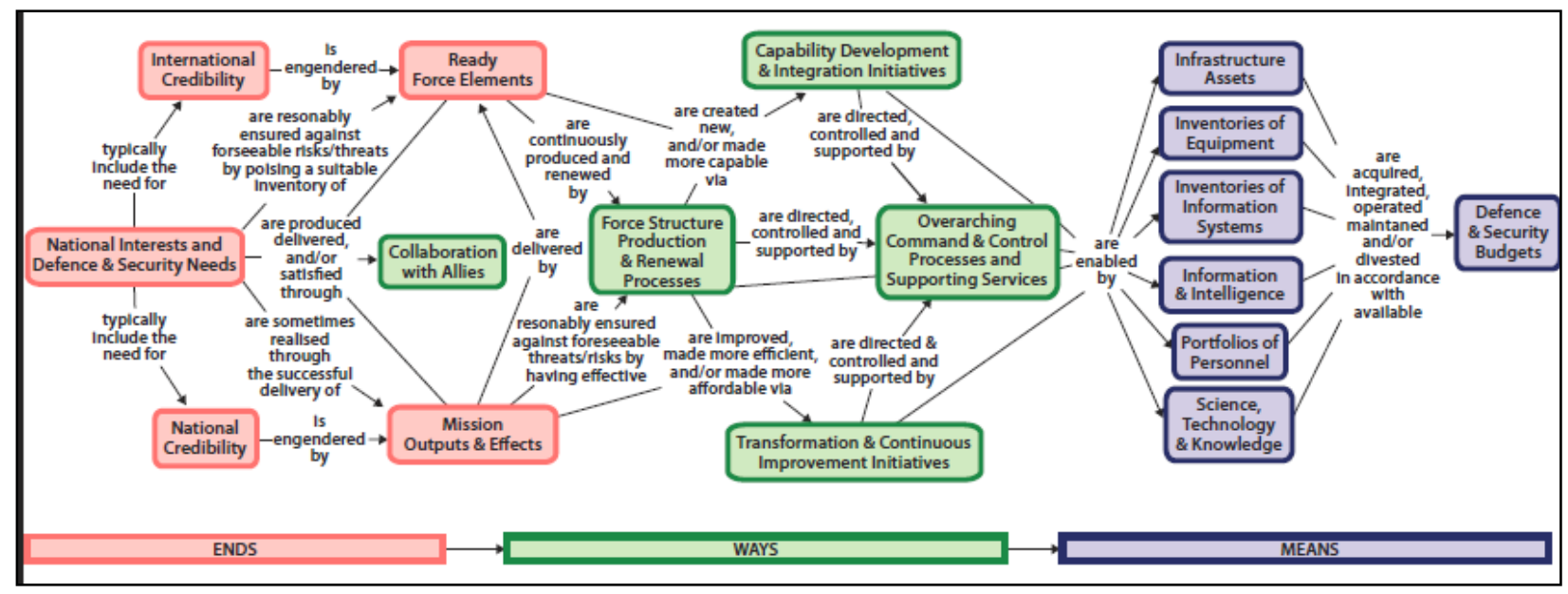




\section{Figure Caption List}

(1) Figure 1. Illustration of Phase 2: Concept Map for a Participating Nation

(2) Figure 2. The Generic, Comprehensive, and Strategic-Level Defence Performance Measurement Framework 